\title{
Development and characterization of thirteen novel microsatellite markers for use in Greenland sharks (Somniosus microcephalus), with cross-amplification in Pacific sleeper sharks (Somniosus pacificus)
}

\author{
Meaghan A. Swintek and Ryan P. Walter * (D)
}

\begin{abstract}
Objective: The objectives of this work are to isolate, develop, and characterize polymorphic microsatellite markers for use in Greenland sharks (Somniosus microcephalus).

Results: Thirteen microsatellite loci were successfully amplified and yielded multi-locus genotypes for $36 \mathrm{~S}$. microcephalus individuals from Grise Fjord $(n=16)$ and Svalbard $(n=20)$. Each locus yielded between 2 and 9 alleles and observed heterozygosity ranged from 0.11 to 0.70 when estimated across both sites. One locus and three loci deviated from HWE following Bonferroni correction, for individuals sampled from Grise Fjord and Svalbard, respectively. Cross-amplification was successful at every locus for five of the ten S. pacificus individuals.
\end{abstract}

Keywords: Somniosus, Greenland shark, Population genetics, Microsatellites, Sleeper shark

\section{Introduction}

Greenland sharks (Somniosus microcephalus) are long lived [1] and presumably late to mature [2] sharks capable of extensive migration [3] in the North Atlantic to Arctic marine environments. Previous molecular genetic work successfully differentiated Greenland sharks from other species in Somniosus [4] and revealed hybridization with Pacific sleeper sharks (Somniosus pacificus) [5, 6], however, knowledge of their population-level genetic variation is yet to be described.

Highly variable molecular genetic markers, such as microsatellites, can provide data to characterize population genetic structure, and have proven useful for describing spatial genetic variation in widely distributed

\footnotetext{
${ }^{*}$ Correspondence: rwalter@fullerton.edu
} California State University, Fullerton, USA elasmobranchs [7-9]. Here, we isolate, develop, and describe polymorphic microsatellite loci to provide molecular genetic markers for assessing the populationlevel genetic variation in the Greenland shark. Thirteen markers were identified as possible candidate loci for population analyses in Greenland shark samples collected from two locations in the Arctic. We also explored marker cross-amplification in Pacific sleeper sharks, providing evidence of utility in other Somniosus species.

\section{Main text \\ Methods}

Primer sets for 50 candidate microsatellite loci were constructed from reduced-representation genomic DNA sequence data from a single Somniosus microcephalus individual sampled from Resolute Bay (SRA accession: PRJNA655731). Genomic DNA from this individual was prepared using the QIAgen DNeasy 
Tissue Kit (Valencia, CA, USA) and shipped to Global Biologics (Columbia, MO) where a library was created with SPRI selection targeting $450 \mathrm{bp}$ inserts. The library was pooled with other species libraries and sequenced on an Illumina HiSeq 2500. Approximately 4 million 250 bp PE reads were recovered; from these, tetrasat motifs with a minimum of five uninterrupted repeating motifs (e.g. GACAGACAGACAGACA) were targeted using STR finder in Galaxy [10] and PCR primer regions flanking each motif were identified using PRIMER3 [11]. A total of $36 \mathrm{~S}$. microcephalus sampled from two sites (Grise Fjord: $n=16$; Svalbard: $\mathrm{n}=20$ ) were used to characterize and optimize the prospective microsatellite markers, and an additional ten $S$. pacificus individuals were used to test for cross-species amplification. For all individuals, genomic DNA was extracted and purified from fin tissue stored in either ethanol or RNAlater (Invitrogen, Carlsbad, CA, USA), using the Promega Wizard Genomic DNA Extraction Kit (Promega Corp, Madison, WI, USA), according to the manufacturer's instructions.

PCR reactions occurred in $12.5 \mu \mathrm{L}$ volumes containing $1.25 \mu \mathrm{L} 10 \mathrm{X}$ PCR reaction buffer with $15 \mathrm{mM}$ magnesium chloride (GenScript, Piscataway, NJ, USA), $0.25 \mu \mathrm{L} 40 \mathrm{mM}$ dNTP's (APEX BioResearch Products), $0.25 \mu \mathrm{L} 10 \mu \mathrm{M}$ forward primer, $0.25 \mu \mathrm{L} 10 \mu \mathrm{M}$ reverse primer, $5 \mathrm{U}$ Taq Polymerase (GenScript, Piscataway, $\mathrm{NJ}$, USA), and $0.5 \mu \mathrm{L}$ genomic DNA, with one locus (Smic2) requiring an additional $0.625 \mu \mathrm{L} 15 \mathrm{mM}$ magnesium chloride per reaction. Thermal-cycler conditions consisted of an initial denaturation at $94{ }^{\circ} \mathrm{C}$ for $2 \mathrm{~min}$, followed by 30 cycles of $94{ }^{\circ} \mathrm{C}$ for $30 \mathrm{~s}$ (denaturation), $52-57^{\circ} \mathrm{C}$ for $30 \mathrm{~s}$ (annealing) depending on marker identity (Table 1 ), $72{ }^{\circ} \mathrm{C}$ for 1 min (extension), and a final step at $72{ }^{\circ} \mathrm{C}$ for $1 \mathrm{~min}$ and $30 \mathrm{~s}$. Three loci (Smic2, Smic24, Smic31) required half the time within each cycle (i.e., reduced from 30 to $15 \mathrm{~s}$ and $1 \mathrm{~min}$ to $30 \mathrm{~s})$. PCR products were visualized on a $1.5 \%$ agarose gels for estimated size confirmation, then measured for precise fragment lengths using a Fragment Analyzer (Advanced Analytic Technologies, Inc., Ankeny, IA, USA) according to the manufacturer's protocol. Fragment lengths were scored using PROsize 3.0 software (Advanced Analytic Technologies, Inc., Ankeny, IA, USA), and were binned across samples to account for variation between plate runs. All loci were analyzed for null alleles, stuttering, or large allele dropout using Micro-Checker 2.2.3 [12]. The total number of alleles and observed and expected heterozygosity were calculated in GenAlEx 6.512b [13]. Deviations from HardyWeinberg equilibrium (HWE) and detection of linkage disequilibrium among all loci pairs was determined in Genepop 4.2 [14] for each site separately.
Table 1 Thirteen novel microsatellite markers developed for use in Somniosus microcephalus $(n=35)$

\begin{tabular}{|c|c|c|c|c|c|}
\hline Locus & Sequence $\left(5^{\prime} \longrightarrow 3^{\prime}\right)$ & $\mathrm{T}_{\mathrm{A}}\left({ }^{\circ} \mathrm{C}\right)$ & Range (bp) & Motif & $\mathrm{N}_{\mathrm{A}}$ \\
\hline \multirow[t]{2}{*}{ Smic1 } & $\begin{array}{l}\text { F: TGCCTAGTAGACGCCCCT } \\
\text { AA }\end{array}$ & 52 & 157-189 & CAGA & 7 \\
\hline & R:TGTTCCCAGATGTGTGCATT & & & & \\
\hline \multirow[t]{2}{*}{ Smic2 } & F: GCCTAAGCCACCCTCCTAAT & 57 & $159-167$ & ACAG & 2 \\
\hline & R: CTCCGGCATCTCCACACTAT & & & & \\
\hline \multirow[t]{2}{*}{ Smic4 } & F:TATTTAGTCCCAGCAGTGCG & 55 & $205-233$ & TGAC & 6 \\
\hline & $\begin{array}{l}\text { R: ACTTCGGCGACCATG } \\
\text { TTCTA }\end{array}$ & & & & \\
\hline \multirow[t]{2}{*}{ Smic5 ${ }^{a}$} & $\begin{array}{l}\text { F:TGTTTCAGGAATAGGGAT } \\
\text { GCC }\end{array}$ & 55 & $224-244$ & TCAG & 4 \\
\hline & $\begin{array}{l}\text { R: CAATCATTTATCTTGTGG } \\
\text { AGCCA }\end{array}$ & & & & \\
\hline \multirow[t]{2}{*}{ Smic10 } & F: ATGCCTATGACACTCCCCTG & 52 & $176-204$ & GACA & 6 \\
\hline & $\begin{array}{l}\text { R: ACCTGCCACCCGATTAGT } \\
\text { AA }\end{array}$ & & & & \\
\hline \multirow[t]{2}{*}{ Smic12 } & $\begin{array}{l}\text { F:TGTCCGACCGAAACG } \\
\text { TAAAT }\end{array}$ & 52 & $173-189$ & AGAC & 3 \\
\hline & $\begin{array}{l}\text { R: CCCTCAGCAGAACCA } \\
\text { TTCAT }\end{array}$ & & & & \\
\hline \multirow[t]{2}{*}{ Smic13 } & $\begin{array}{l}\text { F: CCCATAAACAGCGAA } \\
\text { TGACC }\end{array}$ & 55 & $152-164$ & AGAC & 3 \\
\hline & $\begin{array}{l}\text { R: GCCTTTGAACCAAGG } \\
\text { ACAGA }\end{array}$ & & & & \\
\hline \multirow[t]{2}{*}{ Smic15 } & $\begin{array}{l}\text { F: ATGCTTAGGACGGTTCTG } \\
\text { GA }\end{array}$ & 52 & $196-220$ & AGAC & 6 \\
\hline & R: ATCCCTCATCCTGTGGACTG & & & & \\
\hline \multirow[t]{2}{*}{ Smic16 } & $\begin{array}{l}\text { F: CAGTGACAAACATCC } \\
\text { CCAAA }\end{array}$ & 52 & $220-236$ & ATAG & 5 \\
\hline & $\begin{array}{l}\text { R: AAACAGCCTTTCCCC } \\
\text { GTCTA }\end{array}$ & & & & \\
\hline \multirow[t]{2}{*}{ Smic18 } & $\begin{array}{l}\text { F: ACGTAAATACGCCGATGA } \\
\text { CC }\end{array}$ & 52 & $212-224$ & CAGA & 4 \\
\hline & R: GGCCATGAACTTATCCTCCA & & & & \\
\hline \multirow[t]{2}{*}{ Smic20 } & $\begin{array}{l}\text { F: TCCGAACTCTTTTGGCTG } \\
\text { AC }\end{array}$ & 55 & $243-259$ & GACA & 4 \\
\hline & $\begin{array}{l}\text { R: CGTTCTCAGCTCAGG } \\
\text { GATCT }\end{array}$ & & & & \\
\hline \multirow[t]{2}{*}{ Smic24 } & F:TCACTGGTCCGTAATCGTCA & 55 & $205-213$ & GACA & 4 \\
\hline & $\begin{array}{l}\text { R: CCACATCTTCCGGCTCTA } \\
\text { AA }\end{array}$ & & & & \\
\hline \multirow[t]{2}{*}{ Smic31 } & F: ATACGCTTATGACCGCTCCG & 57 & $243-259$ & GACA & 3 \\
\hline & $\begin{array}{l}\text { R: GTCCAAAACACAGAG } \\
\text { CAGGG }\end{array}$ & & & & \\
\hline
\end{tabular}

Includes: Locus name, forward (F) and reverse (R) primer sequences, annealing temperature $\left(T_{A}\right)$, fragment length range in base pairs, repeat tetrasat motif, total number of alleles $\left(\mathrm{N}_{\mathrm{A}}\right)$

a indicates presence of null alleles

\section{Results and discussion}

Of the microsatellite loci screened in Somniosus microcephalus samples, 24 successfully amplified consistently and yielded indications of allelic polymorphism on agarose gels. Following initial agarose screening, 13 loci were further identified through fragment analysis as 
Table 2 Mean descriptive statistics within each site at the developed microsatellite loci

\begin{tabular}{|c|c|c|c|c|c|c|}
\hline \multirow[b]{2}{*}{ Locus } & \multicolumn{3}{|c|}{ Grise Fjord (GF) } & \multicolumn{3}{|c|}{ Svalbard (SV) } \\
\hline & $N_{A}$ & $\mathrm{H}_{\mathrm{O}}$ & $\mathrm{H}_{\mathrm{E}}$ & $\mathrm{N}_{\mathrm{A}}$ & $\mathrm{H}_{\mathrm{O}}$ & $\mathrm{H}_{\mathrm{E}}$ \\
\hline Smicl & 6 & 0.563 & 0.621 & 6 & 0.500 & 0.666 \\
\hline Smic2 & 2 & 0.125 & 0.117 & 2 & 0.150 & 0.219 \\
\hline Smic4 & 6 & 0.438 & 0.738 & 6 & 0.500 & 0.614 \\
\hline Smic $5^{a}$ & 4 & 0.250 & 0.658 & 3 & 0.100 & 0.261 \\
\hline Smic10 & 5 & 0.500 & 0.523 & 6 & 0.600 & 0.736 \\
\hline Smic12 & 3 & 0.375 & 0.404 & 3 & 0.200 & 0.226 \\
\hline Smic13 & 3 & 0.375 & 0.314 & 3 & 0.300 & 0.261 \\
\hline Smic15 & 5 & 0.750 & 0.709 & 7 & 0.650 & 0.770 \\
\hline Smic16 & 5 & 0.688 & 0.645 & 4 & 0.450 & 0.571 \\
\hline Smic18 & 4 & 0.438 & 0.637 & 2 & 0.500 & 0.495 \\
\hline Smic20 & 3 & 0.188 & 0.361 & 2 & 0.200 & 0.420 \\
\hline Smic24 & 3 & 0.063 & 0.354 & 2 & 0.150 & 0.139 \\
\hline Smic31 & 3 & 0.438 & 0.361 & 3 & 0.500 & 0.406 \\
\hline
\end{tabular}

Includes: number of alleles $\left(\mathrm{N}_{\mathrm{A}}\right)$, observed heterozygosity $\left(\mathrm{H}_{\mathrm{O}}\right)$ and expected $\left(\mathrm{H}_{\mathrm{E}}\right)$ heterozygosity for Grise Fjord $(\mathrm{GF})$ and Svalbard (SV)

Italics values indicate significant departures from HWE following Bonferroni correction

a indicates presence of null alleles

having clear fragment length peaks, and were then scored among 36 individuals. All other loci were deemed not suitable due to either monomorphic allele scoring, weak amplification, or the production of multiple $(>2)$ fragments following PCR and thermal-cycler optimizations (Additional file 1: Table S1).

Each locus produced two to seven alleles within each site, with observed and expected heterozygosity ranging from 0.063 to 0.750 and 0.117 to 0.770 , respectively (Table 2). Four loci failed to conform to HWE following Bonferroni correction for multiple tests: Smic 24 at GF, and Smic1, Smic4, Smic16 at SV. Of the 13 loci, a single locus (Smic5) displayed signs of stuttering and possible scoring error, and homozygote excess in both sampling sites. Two additional loci (Smic4, Smic24) displayed homozygote excess in Grise Fjord samples as indicated by Microchecker.

Exact tests performed for each site resulted in deviations from HWE for individuals at one locus from Grise Fjord and three loci from Svalbard (Table 2). Linkage disequilibrium was not present at any locus pair in either site following Bonferroni correction. Cross-amplification at each of the 13 loci was successful in 5 of the $10 \mathrm{~S}$. pacificus samples using the same cycling conditions. Four samples failed to amplify at 1 locus (2 samples at Smic15; 1 sample at Smic18; 1 sample at Smic1) and one sample at 2 loci (Smic1 and Smic18).

Due to the low sample sizes, it is not possible to make statements regarding the biological significance versus sampling artifacts for departures from HWE, homozygosity excess, and presence of null alleles. Nonetheless, these markers will be useful for exploring genetic variation and stock structure in Greenland sharks throughout their distribution. Furthermore, cross-amplification in the closely related Pacific sleeper shark (Somniosus pacificus) extends potential utility to other sleeper shark species.

\section{Limitations}

- Low sample size and/or a priori site-based population designation may be contributing to deviations from HWE, excess homozygosity, and presence of null alleles.

\section{Supplementary Information}

The online version contains supplementary material available at https://doi. org/10.1186/s13104-021-05447-5.

Additional file 1: Table S1. Eleven additional microsatellite loci primer sets that were not further developed due to either lack of polymorphism or greater than two peaks during PCR amplification screening.

\section{Abbreviations}

PCR: Polymerase chain reaction; HWE: Hardy-Weinberg Equilibrium; $\mathrm{N}_{\mathrm{A}}$ : Number of alleles; $\mathrm{H}_{\mathrm{O}}$ : Observed heterozygosity; $\mathrm{H}_{\mathrm{E}}$ : Expected heterozygosity; $\mathrm{T}_{\mathrm{A}}$ : Annealing temperature; $\mathrm{bp}$ : Base pairs.

\section{Acknowledgements}

Aaron Fisk, Kit Kovaks, Christian Lydersen and Nigel Hussey for providing Greenland shark samples. Stacey McIntyre for assistance in molecular methods. Marcos Caprile and Anthony Nguyen for screening and comparing candidate sequence reads. Sharon Wildes and Cindy Tribuzio provided Pacific sleeper shark samples. 


\section{Author's contributions}

MAS performed lab work, analyzed the data and wrote the paper. RPW constructed the design, supervised molecular methodology and analyses, and edited the paper. All authors read and approved the final manuscript.

\section{Funding}

Funding for this work was provided to RPW by California State University, Fullerton startup funds.

\section{Availability of data and materials}

The DNA sequences containing the microsatellite loci from which these primers were developed were submitted to Genbank (SRA accession: PRJNA655731). The datasets generated and/or analyzed during this study are available from the corresponding author upon request.

\section{Ethics approval and consent to participate}

Not applicable.

\section{Consent for publication}

All authors consent to the current version of the manuscript for submission.

\section{Competing interests}

The authors declare that they have no competing interests.

Received: 11 August 2020 Accepted: 8 January 2021

Published online: 19 January 2021

\section{References}

1. Nielson J, Hedeholm RB, Heinemeier J, Bushnell PG, Christiansen JS, Olsen $J$, et al. Eye lens radiocarbon reveals centuries of longevity in the Greenland shark (Somniosus microcephalus). Science. 2016:353(6300):702-4.

2. Yano K, Stevens JD, Compagno LJV. Distribution, reproduction and feeding of the Greenland shark Somniosus (Somniosus) microcephalus, with notes on two other sleeper sharks, Somniosus (Somniosus) pacificus and Somniosus (Somniosus) antarcticus. J Fish Biol. 2007;70:374-90.

3. Campana SE, Fisk AT, Klimley AP. Movements of Arctic and northwest Atlantic Greenland sharks (Somniosus microcephalus) monitored with archival satellite pop-up tags suggest long-range migrations. Deep-Sea Res. 2015;II(115):109-15.
4. Murray BW, Wang JY, Yang S, Stevens JD, Fisk A, Svavarsson J. Mitochondrial cytochrome b variation in sleeper sharks. Mar Biol. 2008;153:1015-22.

5. Hussey NE, Cosandey-Godin A, Walter RP, Hedges KJ, VanGerwen-Toyne M, Barkley AN, et al. Juvenile Greenland sharks Somniosus microcephalus (Bloch \& Schneider, 1801) in the Canadian Arctic. Polar Biol. 2015;38(4):493-504.

6. Walter RP, Roy D, Hussey NE, Stelbrink B, Kovacs KM, Lydersen C, et al. Origins of the Greenland shark (Somniosus microcephalus): Impacts of ice-olation and introgression. Ecol Evolution. 2017;7:8113-25.

7. Karl SA, Castro ALF, Lopez JA, Charvet P, Burgess GH. Phylogeography and conservation of the bull shark (Carcharhinus leucas) inferred from mitochondrial and microsatellite DNA. Conserv Genet. 2011;12:371-82.

8. Vignaud TM, Maynard JA, Leblois R, Meekan MG, Vázquez-Juárez R, Ramírez-Macías D, et al. Genetic structure of populations of whale sharks among ocean basins and evidence for their historic rise and recent decline. Mol Ecol. 2014;23:2590-601.

9. Bester-van der Merwe AE, Bitalo D, Cuevas JM, Ovenden J, Hernández S, Da Silva S, McCord M, Roodt- Wilding R. Population genetics of Southern Hemisphere tope shark (Galeorhinus galeus): Intercontinental divergence and constrained gene flow at different geographical scales. PloS one. 2017;12(9):e0184481.

10. Afgan E, Baker D, Batut B, van den Beek M, Bouvier D, et al. The Galaxy platform for accessible, reproducible and collaborative biomedical analyses: 2018 update. Nucleic Acids Res. 2018;46:537-44.

11. Untergasser A, Cutcutache I, Koressaar T, Ye J, Faircloth BC, Remm M, Rozen SG. Primer3-new capabilities and interfaces. Nucleic Acids Res. 2012;40(15):e115

12. Van Oosterhout $C$, Hutchinson WF, Wills DPM, Shipley P. Microchecker: software for identifying and correcting genotyping errors in microsatellite data. Mol Ecol Notes. 2004:4:535-8.

13. Peakall R, Smouse PE. GenAlEx 6.5: genetic analysis in Excel. Population genetic software for teaching and research-an update. Bioinformatics. 2012;28:2537-9.

14. Raymond M, Rousset F. GENEPOP (version 1.2): population genetics software for exact tests and ecumenicism. J Heredity. 1995;86:248-9.

\section{Publisher's Note}

Springer Nature remains neutral with regard to jurisdictional claims in published maps and institutional affiliations.
Ready to submit your research? Choose BMC and benefit from:

- fast, convenient online submission

- thorough peer review by experienced researchers in your field

- rapid publication on acceptance

- support for research data, including large and complex data types

- gold Open Access which fosters wider collaboration and increased citations

- maximum visibility for your research: over $100 \mathrm{M}$ website views per year

At $\mathrm{BMC}$, research is always in progress.

Learn more biomedcentral.com/submissions 